\title{
Popular Musics of India: An Ethnomusicological Review
}

\author{
Devpriya Chakravarty ${ }^{1}$ \\ MICA, Ahmedabad, India
}

\begin{abstract}
This article brings into discussion the presence of a contemporary popular music culture amongst globalised, urban, Indian youth which is perpetuated by Electronic Dance Music (EDM) festivals. This paper begins with the argument as to how there is no one monolithic popular music scene in India by presenting a historical analysis of a timeline for popular musics of India, a scene that has received scanty scholarly attention.

Keywords: cultural studies, ethnomusicology, electronic dance music culture, India, popular music, youth culture.
\end{abstract}

\section{Introduction: At The Convergence Of Cultural Studies And Ethnomusicology}

It is believed to be wise to know where one's epistemic underpinnings originate from before one is to indulge into the scientific enquiry about any research questions. In order to read a twenty-first century popular music scene against the cultural landscape of India, this research lies at the cross-section of converging paths which emerge out from two primary directions: cultural studies and ethnomusicology. This research article gains its perspective from a reciprocal relationship shared between cultural studies and ethnomusicology. It thus becomes beneficial to understand the tenets of each academic orientation to unveil their point of convergence.

As believed by Graeme Turner (2003), cultural studies brings in its fold the very pragmatic aim of serving as a means of knowledge production about the structures we live in. The knowledge thus acquired is the primary contribution of the discipline. Ethnomusicology, as explained by Bill Ivey (2009), is an amalgamation of an anthropological and musicological approach to not only study the sonic elements in music, but also its (cultural) context. As a field, ethnomusicology has been in existence since the nineteenth century, but it wasn't till the 1950s that Jaap Kunst dubbed it so. Being utterly disappointed with the taxonomy of "comparative musicology" Kunst coined the term "ethno-musicology" as he believed the former name being incapable of encapsulating the essence of the field to study sociological aspects of music (List, 1979).

Given that ethnomusicologists study not only just music in isolation but also collect data regarding the sociocultural context within which the music is embedded, defining the field of ethnomusicology and its main tenets have gone through tedious and exhausting debates within and by its own cohort (Fitzgerald, 2019; List, 1979; Miller, 2018; Nettl, 1975). Nettl (1975) manages to extrapolate the main components of all past discussions and offers six probable definitions for "ethnomusicology". The one that aligns with the antecedents leading up to the discussion in this paper would define the field to be the study of music in/as culture. While pointing out at a list of "intellectual issues" within the field, Nettl (1975) tells us how the field has forever long focused on music as an artefact and thus failed to look at music as a process. The 1990s saw the forces of cultural studies give ethnomusicology the slight push towards addressing power and cultural movements. With cultural studies, ethnomusicologists now seem to be empowered with a critical language to articulate their work on music. Yet, the ethnographic base continued to be the hallmark of ethnomusicology (Wong, 2006).

The attempt to define the term 'culture' is one of the most taxing and difficult scholarly tasks. Culture centres the practice of a group of people cultivating their belongingness and identity, along with an order in their everyday lived experience. This practice is centred around beliefs and values held by the same group of people (Shuker, 2005). The field of cultural studies came into being around 1960 s as a counter narrative to the hegemonic power structures in order to tear down the whole high versus low art debate thus attempting to emancipate popular cultural practices (During, 1999).

Cultural studies has been perpetually taken to task for its passion for theory and called out for obsessing over abstract theoretical concepts embellished with elitist and alienating articulation and keeping applied concepts at bay. As a field of study, cultural studies has also been reprimanded for illicit borrowing of methodologies from other fields

\footnotetext{
${ }^{1}$ Devpriya Chakravarty is a final year doctoral student at MICA, Ahmedabad. Her areas of specialisation are popular music studies, cultural studies and qualitative research methodology.

Email address: devpriyachakravarty@gmail.com
} 
without adequate affordances of doing so (Turner, 1990). In order to not only silence such criticism but also show the evolution of the discipline; several scholars in the field initiated counter discussions through their studies to address the allegations against the field. A case study published during this time, Doing Cultural Studies: The Story of the Sony Walkman (Du Gay, Hall, Janes, Mackay, \& Negus, 1997) talks about following a model called the 'Circuit of culture' in order to look at a cultural product through different perspectives thus addressing the key issues and debates in the field. This model describes the coming together of five crucial processes "through which any analysis of a cultural text or artefact must pass if it is to be adequately studied" (Du Gay et al., 1997). These processes being representation, identity, production, consumption and regulation form effective means to unravel a cultural text from more varying vantage points. Although this is only just one example but it helps mark the trajectory of the evolution cultural studies has gone through as a field. By the late twentieth century, the field seemed well equipped to not only be able to coalesce the exploration of an array of socio-cultural sites, but also apply a variety of empirical and critical methodologies (Turner, 1990).

Cultural studies is well equipped to unravel the structures embedded in our everyday lived experiences and as Graeme Turner (1990) claims the true potential of the field lies in reading into cultural texts and it bears within the capabilities of critically questioning the performances of these texts. Being multidisciplinary in its approach, the field can form cohesive forces with allied fields like ethnomusicology and form a valuable tool to comprehend an instance in the popular music scene at a particular space and time. It is where these two colossal fields meet that this article begins its research enquiry into reading Electronic Dance Music (EDM) as a twenty-first century popular culture among the contemporary Indian urban youth.

\section{Unpacking The 'Popular' In Pop Culture}

To gain an insight about a particular cultural flux in the popular music scene in India, it is crucial to ask what is meant by the term "popular" which has had a long and charged history. Both in isolation and in juxtaposition with culture, it has had diverse connotations ranging from unpolished, folksy, base, low and then towards the end of 18th century as widespread. It has also often referred to something being contemporary and thus being subversive to dogmatic ways of the past. In the context of this paper a key question to ask is about the notion of values (and whose values) which is attached to the whole debate of high versus low and elite versus popular culture. Certain concerns around the notion of popular culture arise, as outlined by Strinati (2004). The first being that how and by whom or what is popular culture determined by and from where does it emerge from? Second is on how to read a popular cultural text which may be under the influence of commercialisation? Third is about the position popular culture takes up in the society and that whether it is a tool of subversion or a weapon of indoctrination of the prevalent dominant power structures to maintain the status quo.

Storey (2015) draws out six definitions of popular culture emerging from different schools of thought: (1) well-liked and favoured (2) that which is not high culture (3) mass culture (4) originating from the people (5) a site of negotiation between resistance and incorporation of hegemonic social power structures (6) post-modern view of having no distinct boundaries between high and popular culture. According to Storey (2015), 'good' popular culture should bear the efficacies to re-instate the performer-audience relationship resurrecting it from the horrors of industrialization and urbanization. Within the macro framework of popular culture, when one zooms into the micro instance of popular music the work done by the scholars of Centre for Contemporary Cultural Studies has helped the field develop. The British cultural studies helped in bringing into light the argument of as to how the monolithic view of the pop music industry exploiting youth is 'oversimplified'. Instead they cultivate discussions on reading popular music texts in the socio-cultural context within which it is conceived. This brings into fore the idea of granting agency to the audience of cultural texts.

Choice of music constituting popular culture is never born out of vacuum but it is always culturally generated (Hebdige, 1979)and thus, popular music genres need to be read within its commercial and cultural process (Frith, 1996) keeping in mind that "all music consists of a hybrid of musical traditions, styles, and influences" (Shuker, 2005). I locate the current research in the broader area of popular music studies and ethnomusicology while engaging in ethnographic field work. Popular music studies claim the crudeness of the classification of pop music as a residual category in reference to that which is left behind after the exclusion of art and folk music. The study of popular music calls for dealing with a text which is unstable and contested. Popular music studies connect scholarly thoughts with questions concerning the liaison between socio-cultural power, value and musical meaning (Hesmondhalgh \& Negus, 2002).

Bombay (now Mumbai) is the birthplace of the Hindi film industry of India. Thus, in essence the geographical co-ordinates for Bombay and Bollywood collide. However, with the economic liberalisation of 1991 begun the largescale corporatisation of the Hindi film industry leading to the christening of mass production of Hindi cinema as Bollywood (Punathambekar, 2013). With Bollywood making a substantial mark and Bombay evolving into the financial capital of the country as Mumbai lead to Bollywood, the popular Indian cinema to be theorized as a national 
cinema (Virdi, 2017). Resultantly, nuanced regional cinema fast disappeared under the magnanimous shadow of the Bollywood (Booth \& Shope, 2014). All thing cinematic in India began to be deemed synonymous to Bollywood, even popular music (Beaster-Jones, 2009). Needless to say, the hegemony of Bollywood was shaped by the cultural capital enjoyed by the film industry perpetuated by Indians both living in the country and in diasporic imagined communities. Bollywood became a pop-cultural trope for the socio-cultural events in the country (Bhandari, 2017). The arguments presented here tease out strands on how Bollywood not only reinstates a form of "cultural capital" (Bourdieu, 1984) by endorsing EDM but also the over bearing visual and aural presence of brands at the sites of the music festivals that reverberate the horrors of "cultural industry" (Horkheimer, Adorno, \& Schmid Noerr, 2002), which perpetuates the production of cultural content in capitalist societies However, I do not merely question the new wave of popular culture in contemporary India but I try to investigate the phenomenon by reading the juxtaposition of a popular music culture with the liminal space-time of the three to four days annual EDM festivals. From Manuel's (1993) work, we know how popular music culture in India has developed since early 1990s, because of the economic liberalisation and the growing influence of globalisation on the cultural sphere in the country. However, Indian popular music scene as a whole has been vastly understudied. The history of Indian popular music shares an inextricable nexus with the varying unique music production and consumption instances and conditions specific to the country. When it comes to an instant in the post-colonial Indian popular music scene there have always been more than one influencing factors be it imperialism, post-colonial sentiments, globalisation or the biggest which is Bollywood (Booth \& Shope, 2014).

\section{Popular Musics Of India: Tracing The Trajectory}

Indian popular music scene as a whole has been vastly understudied (Booth \& Shope, 2014; Manuel, 1988). While calling out scholars in ethnomusicology and popular music studies for ignoring the pop music canvas in India, Manuel (1988) makes a concurrent note on how there can never be any one unadulterated form of 'Indian' popular music. Ergo, he continues to press on the need for scholarly attention to be paid to specific genres and musical styles within this larger framework in order to gain insight on the socio-cultural flux at play in the contemporary Indian society (Manuel, 1988). From the scarce amount of literature available at this point, however a simple timeline of the practices of popular music production and consumption can be drawn. Within this trajectory a common claim is that Hindi film music along with its commercial and more popular version of Bollywood music has perpetually occupied a hegemonic grip over mass consumption resonating with ideas of both "cultural industry" and "cultural capital" (Beaster-Jones, 2017; Beaster-Jones \& Sarrazin, 2016; Booth \& Shope, 2014; Cullity, 2002; Duggal, 2018; Juluri, 2003; Kvetko, 2004; Manuel, 1988). However, there are certain points in this trajectory that are important to extrapolate in order to fathom the contemporary twenty first century urban Indian pop music scene: record revolution (1900s) (Kasbekar, 2006; Manuel, 1988), cassette revolution (1980s) (Manuel, 1993) and satellite revolution (1990s) (Juluri, 2003). In this paper, I look at a contemporary moment which is informed not only by the echoes of globalisation carried forward from the satellite revolution but also the percolation of the digital wave, rendering it an urban quotidian leading to a growing familiarisation with the Electronic Dance Music as a global popular music culture.

Kasbekar (2006) provides us with the development of the Indian music industry till the late twentieth century into the following main phases: (1) The 1900s that witnessed intense competition among foreign-owned music companies, (2) The subsequent five decades of monopoly of the record company HMV with Hindi film song being the dominant musical genre (3) The advent of the cassette culture in India resulting in the unshackling of the market from the clutches of HMV in the late 1970s (4) Finally the economic liberalisation that saw the penetration of satellite television channels in the society aiding in the formation of a youth culture as well as transforming the music industry in India (Kasbekar, 2006). Within this rhetoric an important thing to keep in mind would be that film music in India has formed an essential component of its mass culture, and claims a vast audience more diverse in nature than any other music in the subcontinent.

In about a year following the invention of wax recording, commercial records arrived in India around 1902 and by 1908, a pressing factory was set up in Calcutta (now Kolkata) owned by the British. This marked the entry of HMV (His Master's Voice) label that released around 4,000 recordings by 1910 (Kasbekar, 2006). The 1930s witnessed the rise of the Indian film industry and film music chalked out a large section of the populace as its audience. Soon film music became the music favoured by the mass (Beaster-Jones, 2009). For the next forty years, HMV was the sole omnipotent recording label in the Indian music industry. With the arrival of Polydor records in 1961, HMV's monopoly came to an inevitable end. However, the reign of film songs continued and it held on to its position of being the dominant musical genre being produced by the two labels (Kasbekar, 2006).

Commercial Indian Hindi film industry, fondly known as Bollywood, produces thrice as much as many films as compared to Hollywood and has the world's second largest music industry. Bollywood's commercialization and commodification of visual and aural elements play a huge role in the success of the industry (Beaster-Jones, 2009). Even though Bollywood has cleverly penetrated the ubiquitous lived experience of a larger section of the mass, "yet 
independently produced commercial music has existed since the beginning of the century and is constantly growing in importance" (Manuel, 1988). A sudden technological innovation in the form of cassettes in the late 1970s took the Indian music industry by a storm tapping into the underlying currents of the subcontinent's popular music potentials that were lying at the peripherals of the Hindi film industry (Kasbekar, 2006).

Introduction of cassette technology acted as a change agent for change by revolutionising the socio-economic status of the music industry in India. It brought in its fore not only the cassette culture but also acted as a catalyst for musical development in the subcontinent. The cassette revolution represents a moment in the Indian mass-media phenomena that had a lasting socio-cultural impact reifying international information revolution in the late 1970s (Manuel, 1993). Based on ethnomusicological field work conducted in North India, Manuel's research explored consequences of the entry of the cassette technology into the Indian popular music milieu in the late 1970s by reading into the resultant dramatic changes not only in the practices of production of the mass media but also the patterns of consumption of a pop culture text and impact it had on its audience (Kasbekar, 2006). Unravelling the tenets under which the 1980s Indian music industry was transformed due the cassette technology becomes crucial for a latter unpacking of 1991 economic liberalisation and the satellite revolution which bore the urban generation that grew up under the influences of globalised mass-media and fill the list of fest goers in the twenty-first century EDM festivals of contemporary India.

We are looking at now an Independent India in the 1970s, with trade policies highly protective in nature that not only made it difficult but forbade the practice of importing of personally consumed electrical goods. In spite of this there was infiltration of radio and cassette players of the Japanese make in the lives of people, fondly named "two-inones". This was primarily due to the existing practice of home-returned migrant labour forces from the Gulf who brought along with them these low cost technologies as a homecoming symbol (Manuel, 1993). The infiltration of this low cost technology is what aided the cassette culture in Indian homes. Early 1980s independent India's mainstream media-scape had two dominant divisions: print media segment and radio and television media segment. While the print media at this point was largely owned by private enterprises, the broadcasting media of television and radio was still solely under the State control and ownership (Dasgupta, Sinha, \& Chakravarti, 2012). Dissemination of Hindi film songs as well as regional and Indian classical music was aided by the role played by Indira Gandhi, the then Prime Minister, who had made sure the efficient penetration of the State-owned media of television and radio which restricted its content to the afore mentioned genres of music. It was not till 1984 when Indira Gandhi's son, Rajiv Gandhi came to be the Prime Minister upon her demise that some changes were beginning to take place. In order to strengthen his image as the new age, modernist Prime Minister, Rajiv Gandhi brought down the import duty taxes on electrical goods while also easing up the restrictions on such goods. This increased not only personal consumption of electrical goods but also made it significantly easier to now locally manufacture goods as importing of components had now become less challenging legally (Manuel, 1993). On retrospect this was the first albeit small State initiative towards liberalisation of the economy back in 1984 (Kasbekar, 2006).

With the changing waves in the country, Japanese companies felt encouraged to establish collaborations with Indian companies, courtesy the new State policies in place after 1984. A significant increase in the sale of both cassette players and records were witnessed due to some of the following impetus: (1) an increased annual growth of consumer electronic goods by 5\%; (2) increased income of the migrant labour force from the Gulf; (3) decrease in cost of the raw materials of electronic goods; (4) local manufacturers' easier access to such raw material. This resulted in a growth in the sale of locally made cassettes to coincide with the growing number of cassette player owners (Manuel, 1988, 1993). By 1990, India had managed to secure the second position, following USA, in the list of consumers for cassettes. Sales had gone up from "US\$1.2 million in 1980 to US\$12 million in 1986 to over US\$21 million in 1990" (Kasbekar, 2006).

Cassette recorders came with certain embedded features and potentials that made it easy for it to expand its reach in the Indian subcontinent. First of all, they were inexpensive along with being portable. Cassette players worked both on battery and electricity as opposed to the older record players that were cumbersome and required an unremitting supply of electricity and all of this apart from being expensive (Manuel, 1993; Kasbekar, 2006). The crucial aspect of the cassette revolution in India, lay not only in the fact that there was a new easy and cheap technology available to the mass for listening to music but instead in the affordances of the technology granted to the audience to be able to record music (Manuel, 1988). This opened up a Pandora's Box of possibilities for the owner of a cassette player to be a producer, distributor of music and not be confined to be a consumer of the same. This simple technology granted agency to a person to be able to choose to listen the musical genre of choice. Audiences were no longer at the mercy of the monolithic genre of Hindi Film Music being meted out as the mass culture. Even the era of a monopolistic music producer came to an end since recording music and distributing the same had become easy and inexpensive (Manuel, 1993). They could now record and listen to music that resonated with their own lived and cultural experiences which lead to surfacing up of a plethora of musical genres that were earlier marginalised by the omnipresent film music (Beaster-Jones, 2009; Manuel, 1993). Amongst these newly recognised genres devotional and regional folk music 
achieved significant commercial success. The humble cassette made way for the mass to be able to afford recorded music and gave space for heterogeneity of musical genres by replacing the gramophone (Kasbekar, 2006; Manuel, 1988 , 1993). This dramatic restructuring of the Indian popular music landscape is important for it helps us to fathom what happened next: satellite revolution.

The recent socio-economic history of India is marked by two major ruptures: first, the transition from a colonial era to a post-colonial one in the late 1940s and second, the transition of the broadcasting media from being State-controlled to being liberated to an open market system in the 1990s. This was the dawn of economic liberisation of 1991(Dasgupta et al., 2012). Thus the year 1991 marked the underpinnings of a new beginning wherein Indian State officially assumed neoliberal economic reforms as the official market policy and the thrust of governance (Kasbekar, 2006). This lead to what would later on be referred to as the satellite revolution and which later pave the path for the growth of electronic media (Juluri, 2002). While the length and breadth of the political economy dimension in this transition is crucial, one often forgets to assign importance to the concurrent and equally significant dimension of cultural economy and its impact. The satellite era is inextricably linked with the macro process of globalisation (Dasgupta et al., 2012). At this point Appadurai's (1996) categorisation of the global cultural economy into five "scapes" helps in making an investigation into the inherent media flow in journey of the cable television channels from entering into the liberalised Indian market to the status of the ubiquitous media in the forthcoming years (Dasgupta et al., 2012).

It is stipulated that the television audience in India came into its form in the 1990s with the advent of global media corporations and their Indian collaborations in the backdrop of a multichannel televisual environment (Juluri, 2002; Zuberi, 2002). Before the economic liberisation, Doordarshan, the State broadcasting network enjoyed a comfortable monopoly in the television networking world. The advent of the neoliberal form of governance the market was opened up to private cable television networks. Consequently, Doordarshan had to compete with an array of private cable channels and in spite of an established wide reach, its popularity dwindled. Doordarshan was under tremendous pressure to survive the intense competition, now with reduced State funds (Kasbekar, 2006). Dramatic changes in terms of what it meant to watch television in the 'liberalised' India has to do a lot with the rise in the number of music based programmes. A new genre of music programming in the form of 'count-down' took the audience by a storm. Sooner than later all the channels had their own version of this new format including the State network of Doordarshan with Hindi film song being the preferred genre. However what soon followed suit was the affordances offered by the advent of music television channels like MTV and Channel [V] to carve out a youth market (Juluri, 2003). "Music television has been so influential that those who have come of age in the post-liberalization era are routinely described as part of the 'MTV generation"' (Zuberi, 2002). The echoes of what it meant to be an audience of MTV back in the 90 s can still be heard in the contemporary articulation of what lead to an inclination towards international popular music.

The echoes of what it meant to be an audience of MTV back in the 90s can still be heard in the contemporary articulation of what lead to an inclination towards international popular music. During my interactions with 26-yearold Tim, who works as a DJ in Kolkata, West Bengal about his choice in music and how these choices were shaped, apart from his peers in his boarding school he could make a clear connection with music television channels like MTV.

I was in a boarding school in Kalimpong. It was during the only during the two months long winter vacations that I would go home and tune into MTV. It was a big hit back then. Especially, if you were into western music. Nowadays MTV has lost its charm. VH1 is decent now. (Tim)

Although, Film music has had dominated the commercial music space in India since the 1930s, music television channels like MTV and Channel [V] have played a monumental role in introducing the new age audience to international musical genres and in the production of new forms of popular music. In order to understand the contemporary Indian popular music scene, one has to look critically at the stepping stones of the formation of what is known as the MTV generation, the introduction of channels like MTV and Channel [V] into the living rooms of a certain socio-economic class of the populace and the undercurrents of the forces of globalisation acting through the media scape (Zuberi, 2002). A crucial feature of MTV, other than playing international pop musics, was the introduction of a TV personality of the VJ (video jockey) who spoke in a certain manner, in a certain accent and about certain music related topics which birthed an insatiable curiosity towards a global popular culture (Juluri, 2002, 2003). Aired during the late 1990s and early 2000s certain shows on MTV granted the audience the agency to select the music videos they wished to watch and also helped their audience the sense of belonging to a larger community of music listeners who had similar tastes and styles in their choice of pop music. My interaction with Mumbai based 28 year old 
DJ, Darshan wherein he encapsulated certain redeeming factors of his early teenage MTV watching days, helps in understanding the formation of a new popular music scene in the urban cosmopolitan spaces of the country.

I remember watching MTV select with Nikhil Chinappa back in my school life, perhaps early teens. You could call in and tell him to play your favourite songs. I remember songs by Savage Garden and others which I could not have otherwise gotten to even know about had it not been for such shows. Back in my day watching MTV was the definition of being cool! You could feel an instant connect with someone who was a fellow MTV 'watcher' (Darshan)

While the 1980s revolutionised the Indian popular music landscape with the arrival of the cassette technology (Manuel, 1993) and the 1990s brought in a new phase of satellite music television audiences (Juluri, 2003) the early 2000s saw technological innovations in the form of CDs (compact discs) that reinstated the decentralising mechanism of the music production and consumption in the broader range of popular musics in India (Manuel, 2014). CDs were fast replacing cassettes because of the extended storage capacities and MP3 players had soon flooded the market making CDs inexpensive to both own and play. What came next around were VCDs (video compact discs) and these restored the visual element to the music consumption culture and rendered the cassette culture to a solely aural experience (Manuel, 2012). Around 2005-2007, VCDs were followed by DVD (digital video disc) that had the storage capacities of around five VCDs. Such technological innovations had two primary impacts. First, the dissemination of music outside the realm of Hindi film song was reinstated. Marginalised genres like regional, folk and devotional which once saw the light had again gone back into the shadows due to satellite channels encashing on the social capital of Bollywood and promoting a global flavour of international pop music. Secondly, for the section of the population that were urban, cosmopolitan and interested still in the global pop culture, these technologies meant they could have more storage for their favourite genres of music while having easy access to the CD-players that were a concurrent part of the deal (Manuel, 2014).

The next wave of digital revolution came in the form of the Internet. Talking about the internet requires admitting to oneself about certain socio-economic privileges of the audience in question without which they would not have access to same. What the Internet did back in the beginning of the twenty-first century in a small way and does it till date on a grander scale is give to its audience a platform to participate in a global culture (Manuel, 2014). Apart from forces of globalisation being reinforced, the Internet aided in opening up the whole universe of global popular musics its audience.

Since winter vacations were the only time for me to visit home and my boarding school had no television sets, I remember going to these Internet cafés with my friends back in High School on Sundays, dressed in our low waist jeans to listen to our favourite Hip Hop and R\&B artists. (Tim)

The twenty-first century saw rapid technological developments in the shapes and forms of not only Internet but smart phones and other such hand held devices that could connect to the Internet with minimised tariffs. The most distinctive way of dissemination of music online takes place websites like YouTube that offer features like downloading, online streaming and even sharing (Manuel, 2014). YouTube and other similar platforms helps the listener search for music online in order to expand their horizon even within their favourite genre. YouTube offers many interesting features that enable the user to not only find music and share it but discuss about it together online.

YouTube is very helpful. For me especially both as a DJ and as music enthusiast. The trending feature helps me find songs that are popular and followed by others. This then helps me choose what to play when I perform and also come across new songs out there. (Darshan)

India should be reckoned as not only a land of cultural diversity but also as a land of paradox. The subcontinent of India is embroidered by an escalating middle class population that has a high purchasing capacity (Dasgupta et al., 2012). The youth within this section are privileged not only because of their economic capital but also social and cultural capital as they represent the experiential modernity of a post-colonial developing nation (Saldanha, 2002). "This class, for better or worse, is eager to be an integral part of the globalizing liberalizing world" (Dasgupta et al., 2012).

Growth in India music production has seen a rise of $13 \%$ from 2015 to 2016 . While in the everyday consumption of music in Indian media industry has taken a turn towards the digital platforms due to reduced data 
tariffs there has also been an increase in Live Events (LE) and Intellectual Property (IP) events like music festivals of 20-26\% from 2015 to 2016 and 100\% over the past two-three years (FICCI Frames, 2017). Statistics of such sorts tell a tale of a new form of music scene, albeit urban and cosmopolitan, emerging at the horizon of India. While Bollywood continues to enjoy a "cultural capital" (Bourdieu, 1984) through mass appeal, a popular music scene has been developing both within and without Bollywood that belongs to the meta-genre of Electronic Dance Music (EDM) and that is practiced at EDM festivals (Kaushik, 2015). Popular music genres have always existed on the margins of the hegemonic Hindi Film Songs but depending on the technological innovation looking the country in the eye these genres either widened its reach or shrunk back (Manuel, 1988). An argument for the growth of the various popular musics in India that lie on the periphery of Hindi film songs is that these forms of musical practices offer sonic experiences that draw far more from personal lived experiences than Bollywood ever does (Gokulsing \& Dissanayake, 2009).

The Indian subcontinent bears an unapologetic linguistic diversity which inevitably puts up a hindrances in the development of one pan-Indian popular music (Manuel, 1988) Thus the idea that "...because people are polyrhythmic they are therefore able to relate to a variety of rhythms and musical tastes across cultural borders" (Parker, 2014), seems to throw more light into the massive popularity of EDM, a western super genre in a country like India. Electronic Dance Music Festivals has trickled down not only to certain parts of the subcontinent calling these as its liminal playgrounds once a year but the sonic vibrations has joined forces with Bollywood music, which still continues to dominate the Indian music industry. These festivals happen at a large scale and the whole process takes on a grand scale from sale of tickets online to actual performance with participation of Indian urban youth from all over the subcontinent. Events like EDM festivals have earned a separate section in FICCI Frames by KPMG, India's Media and Entertainment industry report. In this paper, an attempt has been made to bring together the long and detailed history of the varied popular musics of India to draw a succinct timeline of popular youth culture and their music consumption patterns (See Table 1).

Table 1.

Effective summary of the trajectory of the political economy of the popular musics in India

\section{The pop-music period Date Description}

Record Era

$1900 \mathrm{~s}$

Gramophone Company of India; HMV records as the omnipotent label and Film Songs as the sole genre.

Cassette Era

1980 s

Satellite Era

$1990 \mathrm{~s}$

Digital Era
Late 1990s and early 2000 s
Decentralising the music production industry by breaking through the monopoly of HMV. Peripheral genres surface up with cassette player owners playing multiple roles of the producer, distributor and consumer. Bollywood continued to be the dominant genre.

Economic liberisation opened the broadcasting market to private enterprises. Multichannel televisual environment lead to the birth of music television under the names of MTV and Channel [V]. Along with Bollywood, Indi-pop emerged and music television audiences began to acquire a taste for international popular music.

Internet made accessing global popular music easier and storage devices of the likes of CDs, VCDs and DVDs and later on pen drives and so on made storage far easier than the cassette days. 


\section{Electronic Dance Music As The Contemporary Indian Pop-Music Scene}

Patented by their distinguishing markers of behaviours and thinking, from a deviant subculture (Meyers, 1958) of underground movements in UK and USA in the 1970s-80s, electronic music culture has emerged into a global youth culture. Electronic dance music (EDM) is an umbrella term denoting a myriad of musical sub-genres and styles of the likes of house, techno, trance, drum ' $n$ ' bass and many more. In spite of being aware of the inherent differences of each of these sub-genres, EDM fans tend to view them all under one over-arching category. All the sub-genres that can be clubbed under EDM have definite shared musical traits and qualities that bring these together and can be defined by shared practices of both consumption and production. However, there are two salient features that distinguish EDM from other genres. First, is the usage of electronic technologies of the likes of synthesizers, drum machines, sequencers, and samplers among many others. Second, is the setting of a live performance which generally forms a key feature in the performance of EDM as a cultural practice. As a genre EDM can be experienced in varying contexts like raves, dance parties, night clubs, at a music festival and so on. Historically EDM has had always been intertwined with the dance floor experience and what makes it a child of the modern era is the notion it carries with itself of dancing to recorded music, a tradition that surfaced in the late nineteenth century (Butler, 2003).

As Colombo (2010) points out, "there are many beginnings to the history of Electronic Dance Music (EDM)" but mostly its origins can be traced back to the underground music movements in the United States that became widely popular in the United Kingdom and also spread rather quickly to parts of East Germany in the 1970s (Brabazon, 2012a; Butler, 2003). Till the 1980s the two major sub-genres within EDM were House and Techno, it was however the 1990s that saw further intricate diversification within EDM With the innumerable genres within the $21^{\text {st }}$ century EDM, it becomes difficult at times to call it a genre and thus Parker (2014) dubs EDM to be a super-genre. It would be remiss to not grant disco the due credit for playing its role in evolution of EDM (Colombo, 2010). While never revealing a true space of origin, proper, EDM only came with aural markers: "undressed of lyrics and the biography of an artist, it was cosmopolitan, transcultural and diasporic" (Brabazon, 2012a).

Dearth of record labels and other such physical and empirical evidences only make it harder to chart down an evolutionary tree of electronic dance culture. However, from the little that is known, a few observations become inevitable. From what was a rebellious UK underground rave scene: all night dance parties, involving substance usage located at properties that never belonged to any of the participants, dance culture has evolved into contemporary EDM. Contemporary EDM is coloured by large scale sponsorships that form backbones of these huge, annual EDM festivals allowing event management organisations to commodify dance culture. Twenty-first century EDM thus can be reckoned as the commodified version of what used to be the 1980s dance culture (Toynbee, 2000). In this entire narrative, a crucial take away would be to note how the music scene has never stopped evolving. EDM artists do not show any signs of slowing down and the spectrum of genres within the larger category keeps expanding. EDM artist are famously known for expanding historically known genres and/or combing them into new soundscapes (Brabazon, 2012a; Butler, 2003). "Dance culture is cyclical, but the rise in technology allows the modern artists to express themselves through the present, whether or not they recycle ideas, phrases, or the music itself "(Colombo, 2010).

Although the epicentres of EDM continued to be in Europe and parts of United States, new genres and styles began to set up camps at new scenes. One of these by-products was Goa trance, in India created by the western expatriates who had remained behind after the closure of imperialistic project of 'Portuguese colonisation' of the beach town (Johnson, 2015). Goa trance is thus one of the many various popular electronic dance music genres, having its roots deeply dug into techno and house, much like most other sub-genres within EDM. Associated currently with the broader category of psychedelic trance, it initially formed its distinguished sonic expression. By the late twentieth century, it had managed to travel to Europe to gain popularity and by the twenty-first century it had begun to attract travellers in hordes to beaches of Goa to get a taste of Goa trance (Taylor, 2001). As it travelled offshore to become a globally recognised sound, it did so by imbibing iconography from Eastern culture and religions like Hinduism and Buddhism (St John, 2013). Goa trance attributed the peace-love-unity-respect aspect to psychedelic trance scene owing it its spiritual aspects and attracted ravers from all over the global rave community (Saldanha, 2007).

EDM in the current times is no longer restricted to its 'underground' status especially in India with Bollywood remixes using EDM beats to annual EDM festivals it is part of the mainstream. The extent to which it has marked its place in India is evident from the naming of these remixes as 'Bolly-EDM' (Kappal, 2016). EDM festivals like EVC (Enchanted Valley Carnival), Sunburn, VH1 Supersonic having a combined audience of 200,000 in 2015 (Lobo, 2015) have "taken India's young, affluent urban populations by storm." (Bhat, 2014) Mostly free from lyrics the sole purpose of this rhythm based genre is to get crowds swooning. EDM's orientation to instrumentality aids in the creation of its global sonic communities (Brabazon, 2012b). EDM is a musical super genre that has seemingly capitalized on sounds that technologically produced to form a successful form of pleasure laced tourism industry advocated towards young adults. What makes it significantly different from previous genres is the dependency on lyrics to narrate a story giving freedom to EDM artists to capture their audience through sounds and not through narrative. EDM has acquired a global appeal through dance oriented events by pop culture artists like Skrillex, David Guetta, Calvin Harris and Avicii to 
name a few (Kruger \& Saayman, 2016). Empowered by technological innovations and a lyric-free beat, EDM has landed in India and doing what it did perhaps in the UK and USA a decade ago, but its percolation into the mainstream Bollywood music only makes it seem like it is here to stay (Fazia, 2010). A significant purpose, thus this research article aims to contribute new knowledge about global patterns of youth cultural leisure and lifestyle by bringing to fore discussions about pop-cultural performances in a country that has, thus far, been little researched.

\section{Conclusion: Is This The Dawn Of A Festival Era?}

We live in the media saturated, increasingly globalized, and late capitalist economy of the $21^{\text {st }}$ century marked by the distant din of electronic dance music. EDM reifies the role of media in the construction of our social reality. EDM culture is coloured by globalised urban youth whose common grounding is their ambivalent relationship with both technology and media. Artists both producing and performing EDM opt to blend celebration and critique of media texts and inflict upon their listeners new messages both ironical and ambiguous in nature. EDM production is marked by the presence of three crucial elements: the role of the DJ (the one who mixes the tracks), the role of the producer and the role of the dancer. Mark J. Butler's (2003) doctoral thesis Unlocking the Groove: Rhythm, Meter, and Musical Design in Electronic Dance Music focuses primarily on the DJ, the producer and the hybridity of the two roles.

Electronic Dance Music (EDM) has many facets in India. Although it shares its macro-patterns of production and consumptions with the larger global pop culture it belongs to, when it comes to making an enquiry into EDM practices in India, one must bear in mind the scene birthed in this particular space in the global south varies largely from its estranged kin. EDM in India has different implications for different parts of the subcontinent. While for most it is a rhythmic revolution in the mainstream media of Bollywood music, a certain section of the populace draws another set of gratifications from the practice of electronic dance music culture (EDMC).

In this paper, I have attempted to consolidate the scattered academic discourse on a holistic popular music scene of India to fulfil the following objectives: Firstly, to unpack the present literature on it to be able to unveil the historical timeline of the Indian pop-music setting. Secondly, to understand how the popular musics of India have never been brewed in a cultural vacuum but instead have always mirrored the socio-political economy of the country. Thirdly, to point out how the contemporary, urban and globalised Indian youth identifies with the neo-pop- music culture with the advent of the western rave culture in the form of commercialised Electronic Dance Music (EDM) festivals. Twenty first century the Indian cosmopolitan youth is known to frequent night-clubs, one-day EDM concerts, and annual EDM festivals to escape from their everyday routine lives. Out of the three rave-like contexts, EDM festivals are gaining popularity with the burgeoning infiltration of the pop-music genre in quotidian lives via Bollywood music. These festivals are annual and go on for 2-3 days letting EDM fans from all over the country come together in one specified site and act out their belongingness and identity as a community by affording them on-site camping along with a myriad of communal activities.

The focus of this article has been to bring into light the cultural flux that colours the popular music scene in India. Although Bollywood as the large-scale Hindi film industry makes the most commercial profit and produces a massive chunk of the popular music consumed by the youth of the nation, there are a multitude of other forms of music which are as popular as are commodified. A detailed academic discourse about these cultural performances and youth culture will help shed more light upon the contemporary youth practices of the country. In this paper, I begin with problematising the very notion of both layman and academic understanding of a huge country like India to be a land that just has a one-dimensional popular music scene which is envisioned through Bollywood songs. Through this paper I have tried to draw out the existence of the diverse popular music cultures of prevalent amongst the Indian youth Having attempted an historical analysis has helped me draw an effective timeline of said pop-music-culture and the contemporary era seems to behold within its grasp a festival era throbbing with the sonic vibrations of EDM. Chakravarty(2017) traces the scholarly tradition of privileging traditional religious festivals over contemporary festivals in terms of their ability to offer opportunities of solidarity and building cohesive affordances and thus she discusses practices within popular music festivals to challenge this normative stand by bringing into light again the McGuigan (2005) argument on the formation of cultural public sphere courtesy the sociation of these sites. Festivals are indubitably a cultural process and form a significant aspect of a socio-cultural performance. Festivals may result in emanation of a localised culture or a global culture wherein large-scale music festivals would be an example of the latter. Commercialised as they are, EDM festivals tap on the social currency afforded by the new age global popular culture which makes questions of identity and belongingness insignificant for the organisers who concentrate largely on profit making strategies and logistics circling around footfall (Bennett, Taylor, \& Woodward, 2014).

Twenty first century EDM, both globally and in India, is no exception to how the increasing popularity of a subculture results in the commercialisation of the said cultural text. When EDM originated in parts of Europe and 
USA, these were underground rave parties meant for the collective union of a cohort that had shared values and interests centred around both production and audienceship of the music. However, in the present time and age, although the idea of collective gathering still persists, the events have taken the shape and form of a commodity. People consume the music being produced along with the brand endorsements that embellish the physical sites of these festivals. These events are no longer free of cost as their older forms of underground rave gatherings were and on the contrary the participants pay a hefty price for the total experience. Starting from the price of entry, the fest-goers pay for the camps they put up in $\mathrm{n}$ the site, buy the expensive food available at the site and have to even buy drinking water, all of this apart from the cost they bear to reach the destination. When you enter an EDM fest ground of the likes of Sunburn or EVC, the security will forbid you to carry your own food and drinking supply and they would do this under the garb of making sure no illegal substances are being carried inside. Bereft of all your supplies, you are then left at the mercy of the overpriced items being sold within the grounds. Since the musicians start playing just as the sun begins to set, you are left to venture about the site during your "free" time during which you are lured into the act of buying clothes from expensive brands and/or highly priced merchandise of the artists you claim your fandom for. The sites are usually temporary locations that come to its festival form only during the event duration. Which means that all decorative structures on these sites are temporary and these bear brand endorsements by well-known companies. Some of these brands would capitalise the idea of collective practices of the youth participants of the likes of taking selfies or wanting to try fun sporty events like bungee jumping and so on. For instance, there will always be a "selfie booth" by a popular phone company at the events wherein you will be encouraged to take photos with your group to immortalise the memories using said company's phone. This article is a reminder of how popular culture like EDM and the articulation of the cultural practices through the modern festal performances must thus be investigated keeping in mind the simultaneous commercialisation and festivalisation process that take place at tandem.

Connections between public festivals and community building have thus been time and again cemented by scholarly work done in the past. What becomes interesting to ask here whether something akin to a Festival era succeeded the digital era in the evolution of the Indian pop-music scene. Instead of reducing one to a music television audience or merely finding content online, members of Electronic Dance Music Culture (EDMC) participate in annual ritualistic gathering of the larger community to perform their identity as a part of the cultural text. Thus, this paper aims to extend the trajectory present in literature to encapsulate what the current urban popular music scene amongst Indian youth looks like. Echoes of the large scale EDM festivals are heard even in India, perhaps not on the same scale as the US or UK but good enough to come under purview. The technological bearings and with the fans deeming it more as a "way of life" (SFX, 2015) than music make EDM all the more interesting a site to explore. With this new form of popular music engulfing one and all, keen attention must be paid to both the culture of production and listening of Electronic Dance Music. Curiosity beckons, and the research gap harks back to it with all its charms and cautions.

\section{References}

Appadurai, A. (1996). Modernity at large: Cultural dimensions of globalization. Minneapolis, MN: University of Minnesota Press.

Beaster-Jones, J. (2009). Evergreens to remixes: Hindi film songs and India's popular music heritage. Ethnomusicology, 53(3), 425-448.

Beaster-Jones, J. (2017). A.R. Rahman and the aesthetic transformation of Indian film scores. South Asian Popular Culture, 15(2-3), 151-171. doi:10.1080/14746689.2017.1407551

Beaster-Jones, J., \& Sarrazin, N. (2016). Music in contemporary Indian film: Memory, voice, identity. London: Routledge.

Bennett, A., Taylor, J., \& Woodward, I. (2014). Introduction. In Festivalisation of Culture. Farnham: Ashgate.

Bhandari, P. (2017). Towards sociology of Indian elites: Marriage alliances, vulnerabilities and resistance in Bollywood. Society and Culture in South Asia, 3(1), 108-116.

Bhat, S. (2014). Electronic dance music comes of age in India. Forbes India. Retrieved from http://www.forbesindia.com/article/recliner/electronic-dance-music-comes-of-age-in-india/36919/1

Booth, G. D., \& Shope, B. (Eds.). (2014). Introduction: Popular music in India. In More than Bollywood: Studies in Indian Popular Music (p. 358). New York: Oxford University Press.

Bourdieu, P. (1984). Distinction: A social critique of the judgment of taste (R. Nice, Trans.). Cambridge: Harvard University Press.

Brabazon, T. (2012a). Genre and community. In Popular Music (pp. 180-184). London: Sage.

Brabazon, T. (2012b). Popular music: Topics, trends \& trajectories. Los Angeles: Sage.

Butler, Mark. J. (2003). Unlocking the groove: Rhythm, meter, and musical design in electronicdance music. Indiana University, USA.

Chakravarty, D. (2017). Reading Popular Music Festivals through the Lens of Public Sphere. Jurnal Komunikasi, Malaysian Journal of Communication, 33(1). 
Colombo, A. (2010). From disco to electronic music: Following the evolution of dance culture through music genres, venues, laws, and drugs. (Claremont McKenna College). Retrieved from http://scholarship.claremont.edu/cmc_theses/83

Cullity, J. (2002). The Global Desi: Cultural nationalism on MTV India. Journal of Communication Inquiry, 26(4), 408-425. doi:10.1177/019685902236899

Dasgupta, S., Sinha, D., \& Chakravarti, S. (2012). Media, gender, and popular culture in India: Tracking change and continuity. New Delhi: Sage.

Du Gay, P., Hall, S., Janes, L., Mackay, H., \& Negus, K. (1997). Doing cultural studies: The story of the Sony walkman. London: Sage/Open University Press.

Duggal, V. (2018). Imagining sound through the Pharmaish: Radios and request-postcards in North India, c. 19551975. BioScope: South Asian Screen Studies, 9(1), 1-23. doi:10.1177/0974927618767270

During, S. (Ed.). (1999). The cultural studies reader (2nd ed.). London; New York: Routledge.

Fazia, M. (2010). Rise of the DJ. In Hub: Indian Electronia (pp. 10-13). India: MGMH.

FICCI Frames. (2017). Media for the masses: The promise unfolds (p. 294). KPMG.

Fitzgerald, J. (2019). Peace Up, A-town Down: Exploring the Evolution of Popular Music. American Journal of Qualitative Research, 3(1), 72-92. https://doi.org/10.29333/ajqr/5812

Frith, S. (1996). Performing rites: On the value of popular music. Cambridge: Harvard University Press.

Gokulsing, K. M., \& Dissanayake, W. (Eds.). (2009). Popular culture in a globalised India. London: Routledge/Taylor \& Francis Group.

Hebdige, D. (1979). Subcultute the meaning of style. London: Routledge.

Hesmondhalgh, D., \& Negus, K. (Eds.). (2002). Popular music studies. London: New York: Arnold; Distributed in the United States of America: Oxford University Press.

Horkheimer, M., Adorno, T. W., \& Schmid Noerr, G. (2002). Dialectic of enlightenment: Philosophical fragments. Stanford, CA: Stanford University Press.

Ivey, B. (2009). Ethnomusicology and the twenty-first century music scene (Seeger Lecture presented at the Society for Ethnomusicology Annual Meeting, 2007). Ethnomusicology, 53(1), 18-31.

Johnson, C. (2015). Dance floor reverberations: Affect and experience in contemporary electronic dance music (Master's thesis). Texas A \& M University.

Juluri, V. (2002). Music television and the invention of youth culture in India. Television \& New Media, 3(4), 367386. doi:10.1177/152747602237283

Juluri, V. (2003). Becoming a global audience: Longing and belonging in Indian music television. New York: P. Lang.

Kappal, B. (2016). How EDM became young India's poison of choice. Business Line. Retrieved from http://www.thehindubusinessline.com/blink/watch/how-edm-became-young-indias-poison-ofchoice/article9111420.ece

Kasbekar, A. (2006). Pop culture India! Media, arts, and lifestyle. Santa Barbara, Calif: ABC-CLIO.

Kaushik, P. (2015). India promises to grow big on EDM, entertainment! Business Insider India. Retrieved from http://www.businessinsider.in/India-promises-to-grow-big-on-EDMentertainment/articleshow/47881629.cms

Kruger, M., \& Saayman, M. (2016). A 3E typology of visitors at an electronic dance music festival. International Journal of Event and Festival Management, 7(3), 219-236. doi:10.1108/IJEFM-04-2016-0027

Kvetko, P. (2004). Can the Indian tune go global? TDR/The Drama Review, 48(4), 183-191.

List, G. (1979). Ethnomusicology: A discipline defined. Ethnomusicology, 23(1), 1-4. doi:10.2307/851335

Lobo, K. (2015). EDM nation: How India stopped worrying about the riff and fell in love with the beat. Retrieved from http://rollingstoneindia.com/edm-nation/

Manuel, P. (1988). Popular music in India: 1901-1986. Popular Music, 7(2), 157-176.

Manuel, P. (1993). Cassette culture: Popular music and technology in North India. Chicago: University of Chicago Press.

Manuel, P. (2012). Popular music as popular expression in North India and the Bhojpuri region, from cassette culture to VCD culture. South Asian Popular Culture, 10(3), 1-14.

Manuel, P. (2014). The regional North Indian popular music industry in 2014: From cassette culture to cyberculture. Popular Music, 33(03), 389-412. doi:10.1017/S0261143014000592

Miller, L., M. (2018). Social Networking Strategy for Creating Public Value in Eastern India. Journal of Ethnic and Cultural Studies, 5(1), 85-93.

McGuigan, J. (2005). The cultural public sphere. European Journal of Cultural Studies, 8(4), 427-443.

Meyers, B. (1958). The study of society. New York, NY: Harcourt Brace.

Nettl, B. (1975). Ethnomusicology today. The World of Music, 17(4), 11-15. 
Parker, B. (2014). Beyond capital, towards myth: EDM fandom and dance practice. In M. Duffet (Ed.), Popular Music Fandom: Identities, Roles and Practices (pp. 37-54). London: Routledge.

Punathambekar, A. (2013). From Bombay to Bollywood: The making of a global media industry. New York: New York University Press.

Saldanha, A. (2002). Music, space, identity: Geographies of youth culture in Bangalore. Cultural Studies, 16(3), 337350. doi:10.1080/09502380210128289

Saldanha, A. (2007). Psychedelic white: Goa trance and the viscosity of race. Minneapolis: University of Minnesota Press.

SFX. (2015). Electronic music,technology and youth culture. Retrieved from http://sfxil.com/spcontent/uploads/2015/04/Electronic-Music-Technology-and-Youth-Culture.pdf

Shuker, R. (2005). Popular music: The key concepts (2nd ed.). London; New York: Routledge.

St John, G. (2013). The vibe of the exiles: Aliens, Afropsychedelia and psyculture. Dancecult, 5(2), 56-87. doi:10.12801/1947-5403.2013.05.02.04

Storey, J. (2015). What is popular culture? In Cultural Theory and Popular Culture: An Introduction (Third, pp. 114). London: Routledge.

Strinati, D. (2004). An Introduction to Theories of Popular Culture. Retrieved from http://kcl.eblib.com/patron/FullRecord.aspx?p=200017

Taylor, T. D. (2001). Turn on, tune in, trance out. In Strange Sounds: Music, Technology and Culture (pp. 165-200). London: Routledge.

Toynbee, J. (2000). Making popular music: Musicians, creativity and institutions. London : New York: Arnold ; Copublished in the USA: Oxford University Press.

Turner, G. (1990). Conclusion. In British Cultural Studies: An Introduction (Third, pp. 225-231). London; New York: Routledge.

Turner, G. (2003). British cultural studies an introduction. Retrieved from http://www.myilibrary.com?id=13853

Virdi, J. (2017). A national cinema's transnational aspirations? Considerations on "Bollywood." South Asian Popular Culture, 15(1), 1-22.

Wong, D. (2006). Ethnomusicology and difference. Ethnomusicology, 50(2), 259-279.

Zuberi, N. (2002). India song: Popular music genres since economic liberalization. In D. Hesmondhalgh \& K. Negus (Eds.), Popular Music Studies (p. 272). New York: Oxford University Press. 